\title{
Review
}

\section{Historical Review of the Electrochemical Industry in Japan}

\author{
Takeshi TAKEI \\ Faculty of Engineering, Keio University, Koganei-shi, Tokyo \\ Received Oct., 29, 1963
}

\section{General Survey}

In our country, we have almost all kinds of electrochemical industry which are seen abroad, and they are possessed of advanced techniques on a large scale. But the techniques have been mostly imported from abroad, and the chronological table shows that each of them made its start a bit later than the one in other countries. This is because Japan has long been isolated from western countries remaining undeveloped in industry. It is regretful that we are still unable to pass perfectly out of this condition.

There has been rise and fall in the history of the electrochemical industry in Japan, which represents the situation of the Japanese industry as a whole as well. The first part of the history is until the end of the World War I, during which period they made industrial operation of some small scale techniques introduced from abroad. The beginning of the war made it rather difficult to import goods from abroad and various kinds of electrochemical industry started here and there in our country accordingly. This is the first period of rise in the history.

With the end of the war, a serious depression prevailed all over the world and drove the electrochemical industry in Japan into a great mess and most part of it became obliged to disappear. On the other hand, Japanese hydraulic power generating industry gradually developed and it became possible to passess considerable surplus electric power in wet seasons and at night time. In response to the economic reconstruction at the beginning of the Showa Era, electrochemical industry made its advancement by degree, making use of this surplus electric power at low cost. This time projects were discreetly planned out and the industry took a steady pace ahead. Electrochemical plants came to find their location at some mountainside near hydraulic power generating plants. It was when the industry began to start in the right direction that the Manchurian Incident took place and developed into the China Affair. In such circumstances, this industry, playing an active role in manufacturing wartime materials, achieved a remarkable advancement. Thus, when the World War II began, both government and people tried most hard to promote this industry, and Japan became one of the three big countries of electrochemical industry, in the world. It naturally spread to Korea, Formosa and Manchuria. This is the second period of rise.

As the war proceeded, it became rather difficult to import sources and materials, and the shortage of transportation facilities and the damage by bombardments led the industry to gradual decline, leaving it in a most miserable condition at the termination of the war. After the war, importance was laid on food production preferentially, and the industry of ammonium sulfate and calcium cyanamide made a quick recovery to begin with. The rapid advancement of the development of power sources promoted the electrochemical industry in our country into an unique prosperity. (cf. Table of production trend of chief electrochemical industries). Thus Japan has become one of the leading countries of the electrochemical industry in the present world. But as will be stated later, the electric power has met a difficult problem of supply on account of the industrial expansion and the 
rapid increase of the demand for domestic use, and this has become a serious problem for the electrochemical industry which consumes quite a lot of electric power. Since hydraulic power generating scheme has become unable to meet the demand at home, steam electric power generation has been increasing, consequently raising the power cost. At the same time, in the underdeveloped countries it has become possible to obtain electric power at the cost lower than that in Japan and they can manufacture electrochemical products also at low cost. These circumstances have caused various problems of electrochemical industry in Japan. With a free trade system waiting to be operated, the Japanese industry itself has been struggling hard for the rationalization of production, for instance, lowering of the unit cost of electric power, reduction of transportation fee, development of new products, etc. It seems most probable that the future electrochemical industry will put weight rather on the manufacture of expensive highly qualified goods than that of comparatively cheaper raw materials, bringing up the cooperative production scheme with other industries of closer relation.

\section{Historical Development of Main Electrochemical Processes}

In Japan electroplating marked the first electrochemical industry, which was introduced in 1877. Since then, it has developed to be a highly qualified technique even compared with leading countries, from which advanced techniques were imported now and then. Dry cell appeared next, and Senzo Yai, the founder of the industry in Japan, succeeded in its manufacturing in 1888. Lead storage battery was born in Kyoto in 1894, and alkaline storage battery started in 1931. Japan stands in the least behind the other countries in the battery industry, and the products have been exported to various countries of the world. In electrolytic refining, Furukawa \& Co. first began its study in 1889, and the full scale production started in 1898. Calcium carbide manufucture was begun by
Tsuneichi Fujiyama in 1902. Both of them were introduced techniques from abroad in early times, and it seems that, although they met so many difficulties to overcome in operation, both industries have widely spread and developed into today's prosperity. In 1909 manufacture of calcium cyanamide was started by Tsuneichi Fujiyama, Jun Noguchi and others. Japan started in eight years later than Germany, but its industrial techniques have made an utmost development and it is now calling the attention of the world.

It was in 1909 that Toragoro Tanahashi started the manufacture of potassium chlorate as the material for match, and in the same year electric steel furnace was for the first time operated at Yasuki Steel Manufacturing Co. Phosphorus manufacture had also been studied but the actual production was begun also by Toragoro Tanahashi in 1912. Kuhara Mining Co. started the production of carbon bisulfide by an electric furnace in the same year. Several years that followed were the time when the flowers of electrochemical industry began to come out in a line just as around 1890 in Europe and America. In 1915 electrolytic caustic soda was started by Hodogaya Chemical Ind., Co., electrolytic zinc by Takada \& Co., artificial graphite by Nippon Electric Graphite Ind., Co., and sodium chlorate by Hodogaya Chemical Ind., Co. In 1916 metallic sodium was manufactured by Hodogaya Chemical Ind., Co., and carborundum by Kagoshima Electric Railway Co. It was about this time that manufacture of ferroalloys and electric pig iron, though in a small scale, began here and there in our country. Alundum was also manufactured. But many of these manufacturing were suspended at the termination of the War.

As a new industry, after the World War I, Asano Carlit Co. (present The Japan Carlit) marked the time in the production of ammonium perchlorate in 1920, and we must also refer to the introduction of ammonium synthesis industry into Japan by Nippon Chisso Hiryo (Nitrogenous Fertilizer) Co. Since then, many 
companies tried hard to introduce various kinds of the process and in 1931 Kawasaki factory of Showa Denko (Electric Ind.,) Co. was established with its Japanese original techniques and has developed into today's prosperity.

It was in 1931 that Rikagaku Kenkyujo (Institute of Scientific and Industrial Research) succeeded in producing electrolytic magnesium, and in 1932 refractory materials fused by electric furnace were produced by Asahi Glass Ind., Co. In the same year anodic oxidation of aluminium was developed into process. In the next year Edogawa Chemical Ind., Co. produced hy: drogen peroxide. It was in the year 1934 that electrolytic aluminium which had been studied by many since the beginning of the 20 century at last came to be industrialized by Nobuteru Mori. The difficulty they had to come across many have been partly due to the shortage of aluminium resources in Japan and they had to toil a great deal for a long time. This industry spread to various companies, but with the beginning of the World War II they had to suffer from the shortage of raw materials. It was suspended for a while at the end of the war, but is now quite prosperous. The dry manufacturing method of metallic manganese, which was started by Shin-etsu Chemical Ind., Co., Tekkōsha Co. and others since about 1940 , is an unique one. Electrolytic polishing method has been adopted since 1941. We must also mention that Chōsen Chisso Hiryo (Nitrogenous Fertilizer) Co. succeeded in manufacturing magnesium by the direct reduction method with an electric arc furnace after a hard research study.

Ten years since then passed in the confusion brought about by the second war and the economic reconstruction, and no new attractive products were manufactured. The production of phosphorus fertilizer by electric fusion method was seen in various companies since about 1950 and marked the time in the field of phosphorus fertilizer, but has not developed so much on account of the recent increasing demand for synthetic chemical fertilizers. Sodium chlorite was produced in 1951 by The Japan Carlit, and Hodogaya Chemical Ind., Co. About then, electrolytic nickel (Sumitomo Metal Mining Co.), ferronickel (Nippon Mining Co.), and metallic titanium (Osaka Titanium Ind., Co.) were developed, and in 1956 the production of electrolytic chromium started at Tekkōsha Co. and the production of magnesium by thermal reduction was begun by Furukawa Magnesium Ind., Co., both of which have been in due development.

In the field of semi-conductor, manufacture of germanium and silicon started several years ago, and has developed into an unique prosperity, partly with home techniques and partly with imported ones. The study of inter metallic compound semiconductor has got under way and is in due progress.

As has been stated above, almost all techniques of electrochemical industry in our country have been imported from abroad. Of course, there are some original techniques of our own, and some of the introduced techniques have brought about better achievements than are seen abroad. But one of the big characteristics of electrochemistry in Japan is that most of its techniques have been introduced from outside. Another characteristic is that there exist so many enterprises of smaller scale. Both of the two characteristics are rather fatal to the Japanese industry, and it is necessary for her to get rid of this fate and to manufacture, in the reasonable system, unique and original products in a big scale in the future, when world will become a single large market accelerated by the progress of traffic and transportation. At present especially when the demand for electric power has been rapidly increasing, the circumstances do not allow us to produce at low cost materials and products consuming large amount of electric power. Thus it has become a big problem now to develop original techniques and to make fully rational use of electric power.

Electric power which is used for electrochemical industry alone in Japan for its main products amounted to some $180 \times 10^{8} \mathrm{kWh}$ 


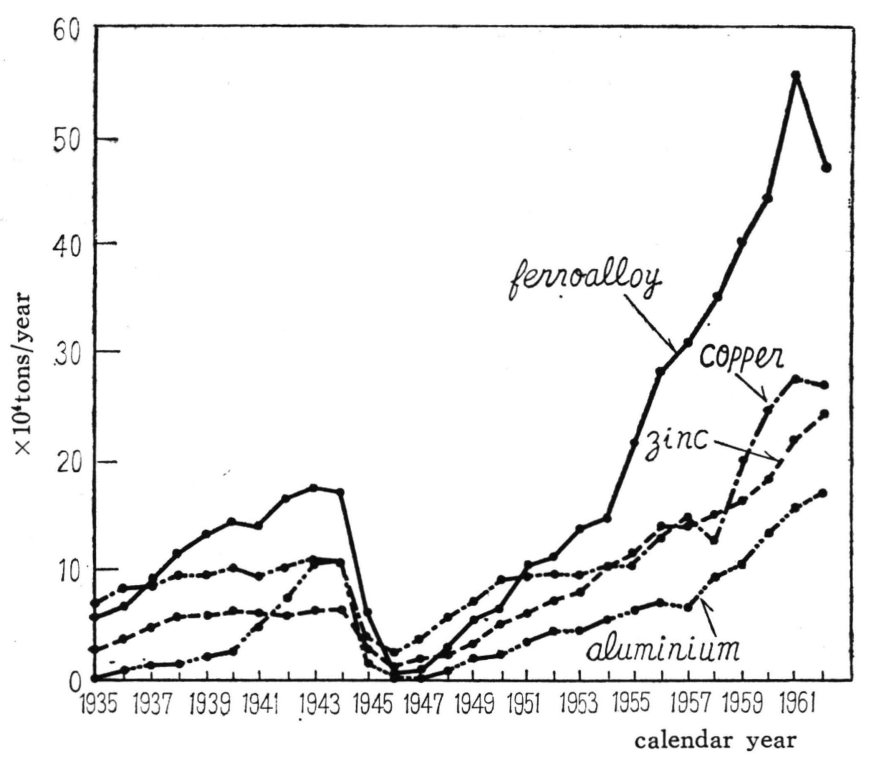

Fig. 1 Electrochemical production of metals in Japan.

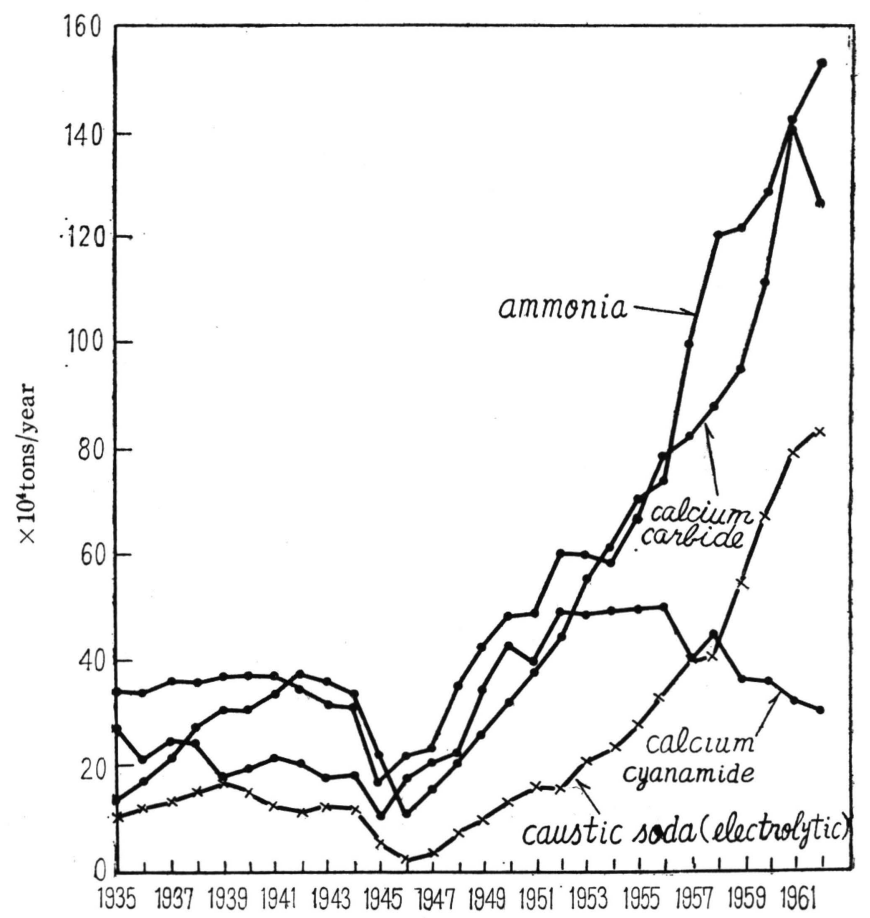

Fig. 2 Production of basic industrial chemicals in Japan. 
in 1962 , which is equal to about $15 \%$ of the whole consumption of Japanese electric power.
Fig. 1 and Fig. 2 show the yearly production trend of Japanese electrochemical industry. 